\title{
Conservation and management of northeast Atlantic and Mediterranean maerl beds
}

\author{
C. BARBERA ${ }^{\mathrm{a}, \dagger}$, C. BORDEHORE ${ }^{\mathrm{a}, \dagger}$, J.A. BORG ${ }^{\mathrm{b}, \dagger}$, M. GLÉMAREC ${ }^{\mathrm{c}, \dagger}, \mathrm{J}^{\circ}$ GRALL $^{\mathrm{c}, \dagger}$, \\ J. M. HALL-SPENCER ${ }^{\mathrm{d}, \dagger}$, CH. DE LA HUZ ${ }^{\mathrm{f}, \dagger}$, E. LANFRANCO ${ }^{\mathrm{b}, \dagger}$, M. LASTRA ${ }^{\mathrm{f}, \dagger}$, P.G. MOORE ${ }^{\mathrm{e} \dagger, \uparrow,}$, \\ J. MORA ${ }^{\mathrm{g}, \dagger}$, M.E. PITA ${ }^{\mathrm{f}, \dagger}$,A.A. RAMOS-ESPLÁ ${ }^{\mathrm{c}, \dagger}$, M. RIZZO ${ }^{\mathrm{b}, \dagger}$, A. SÁNCHEZ-MATA $^{\mathrm{f}, \mathrm{g}, \dagger}$, \\ A. SEVA ${ }^{\mathrm{a}, \dagger}$, P.J. SCHEMBRI ${ }^{\mathrm{b}, \dagger}$ and C. VALLE ${ }^{\mathrm{a}, \dagger}$ \\ ${ }^{a}$ Ciencias Ambientales (Biologia marina), Universidad de Alicante, 03080 Alicante, Spain \\ ${ }^{\mathrm{b}}$ Department of Biology, University of Malta, Msida, Malta \\ ${ }^{\mathrm{c}}$ UMR CNRS 6539 Ecologie benthique, Institut Universitaire Européen de la Mer, Place Copernic, 29280 Plouzane, \\ France \\ ${ }^{\mathrm{d}}$ School of Biological Sciences, University of Plymouth, Drake Circus, Plymouth, PL4 8AA, UK \\ ${ }^{\mathrm{e}}$ University Marine Biological Station, Millport, Isle of Cumbrae, UK, KA28 0EG \\ ${ }^{\mathrm{f}}$ Departamento de Ecologia y Biologia Animal, Facultad de Ciencias, Universidad de Vigo, Apdo.874, 36200 Vigo, Spain \\ ${ }^{\mathrm{g}}$ Departamento de Biología Animal, Facultad de Biología, Universidad de Santiago de Compostela, 15706 Santiago de \\ Compostela, Galicia, Spain
}

\begin{abstract}
1. Maerl beds occur worldwide and are formed by an accumulation of unattached calcareous red algae (Rhodophyta).

2. Maerl-forming algae grow in a superficial living layer on sediments within the photic zone.

3. Maerl beds are spatially complex habitats with a high degree of species and trophic group diversity.

4. The European Commission's 'Habitats Directive' mandates the conservation management of two of the main European maerl-forming species, Phymatolithon calcareum and Lithothamnion corallioides.

5. Mediterranean maerl beds are to be considered for inclusion in national inventories of sites of conservation interest, as required by the SPABIM Protocol of the Barcelona Convention.

6. In spite of their importance, and the requirement for their conservation management, European maerl grounds suffer a variety of anthropogenic perturbations including direct exploitation through extraction, fishing impacts and chemical pollution by organic matter and excess nutrients.

7. The ecology of northeast Atlantic and Mediterranean maerl beds has received little attention, in contrast to other marine communities (e.g. kelp forests, sea-grass meadows).
\end{abstract}

\footnotetext{
* Correspondence to: P.G. Moore, University Marine Biological Station Millport, Isle of Cumbrae, KA28 0EG, UK.

E-mail: pmoore@udcf.gla.ac.uk

${ }^{\dagger}$ Authorship alphabetical: cite as BIOMAERL team

ॠCoordinator
} 
8. Key conservation and management measures proposed include: the recognition that maerl beds are non-renewable resources and cannot sustain direct exploitation; prohibitions on the use of towed gear on maerl grounds; moratoria on the issue of further permits for the siting of aquaculture units above maerl grounds; monitoring of existing exploited or impacted maerl beds; the designation of 'no-take' reserves; measures to limit the impacts that might affect water quality above maerl beds; a programme of monitoring of the 'health' of European maerl beds; an awareness campaign on the biological importance of maerl beds; a higher conservation status for maerl habitats and maerlforming species in European legislation; and further research on maerl ecosystems.

Copyright (C) 2003 John Wiley \& Sons, Ltd.

KEY WORDS: Maerl; rhodoliths; Atlantic; Mediterranean; Habitats Directive; SPABIM; anthropogenic impacts

\section{INTRODUCTION}

Coastal marine ecosystems constitute important resources both ecologically (Parsons, 1992; Norse, 1993) and economically; this necessitates their conservation and management to sustain both ecological characteristics and economic value. Marine biodiversity is threatened by species overexploitation, habitat destruction and environmental changes, including those resulting from the increasing pollution of marine waters (Smith et al., 1999). New management strategies must be employed to promote sustainable resource use. However, these strategies require extensive research on poorly understood marine ecosystems (Bohsanck and Ault, 1996), such as maerl beds.

Maerl beds are characterized by accumulations of living and dead unattached non-geniculate calcareous rhodophytes (mostly Corallinaceae but also Peyssonneliaceae). Also known as rhodolith beds (Steller and Foster, 1995), these habitats occur in tropical, temperate and polar environments (Bosence, 1983; Freiwald and Henrich, 1994). In Europe they are known from throughout the Mediterranean (Jacquotte, 1962) and along most of the Western Atlantic coast from Portugal to Norway, although they are rare in the English Channel, Irish Sea, North Sea and Baltic Sea (Hall-Spencer, 1998).

Maerl beds are often found in subdued light conditions and their depth limit depends primarily on the degree of light penetration. In the northeast Atlantic, maerl beds occur from low in the intertidal to $c a 30 \mathrm{~m}$ depth (Birkett et al., 1998); in the West Mediterranean they are found down to 90-100 m, while in the East they occur down to depths of $c a 180 \mathrm{~m}$ (Basso, 1996).

The EC-funded BIOMAERL project ran from 1996 to 1999 and linked laboratories in the United Kingdom, France, Spain and Malta. It set out to: (1) examine European maerl-bed biodiversity; (2) establish the functional roles played by key elements of the biota; (3) assess the impacts of a variety of anthropogenic assaults on representative grounds; and (4) compile an inventory of northeast Atlantic and Mediterranean maerl-bed biota. The key element of this research was a comparative study of the ecology and biogeography of maerl grounds from Scotland (Firth of Clyde), Brittany, France (Brest) and Spain (Ria de Vigo) in the northeast Atlantic, and Alicante (Spain) in the western and Malta in the central Mediterranean (Figure 1). This paper presents the BIOMAERL team's view of conservation priorities for this habitat and suggests how these may be achieved.

\section{THE IMPORTANCE OF MAERL BEDS}

Maerl beds are analogous to the sea-grass beds or kelp forests (BIOMAERL, 1999) in that they are structurally and functionally complex perennial habitats formed by marine algae that support a very rich biodiversity. The high biodiversity associated with maerl grounds is generally attributed to their complex architecture. Long-lived maerl thalli and their dead remains build up on underlying sediments to produce deposits with a three-dimensional structure that is intermediate in character between hard and soft grounds (Jacquotte, 1962; Cabioch, 1969; Keegan, 1974; Hall-Spencer, 1998). Maerl thalli grow very slowly (Littler 


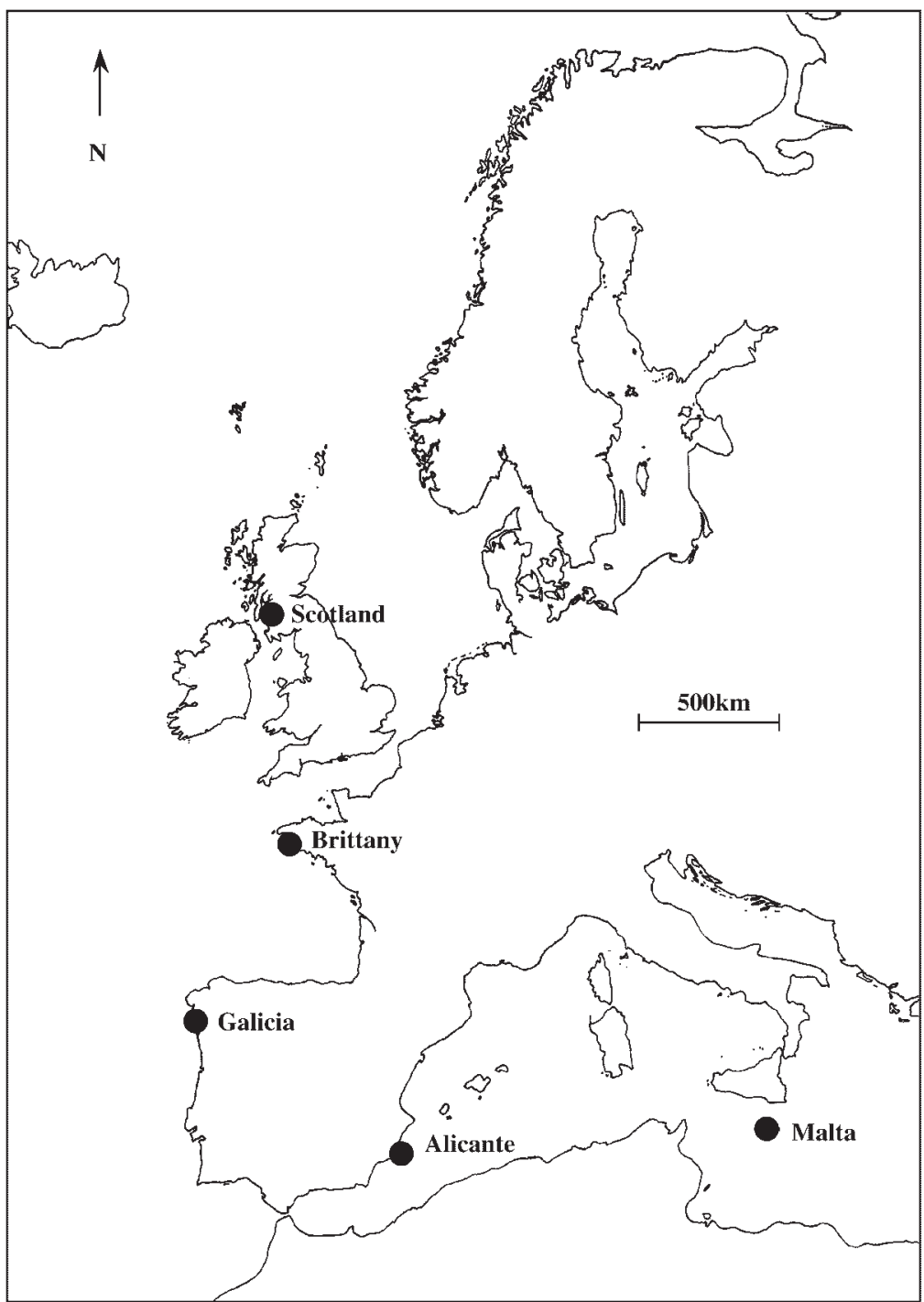

Figure 1. Map showing the location of maerl beds studied as part of the BIOMAERL project.

et al., 1991; Birkett et al., 1998) such that maerl deposits may take hundreds of years to develop, especially in high latitudes (BIOMAERL, 1998). For this reason maerl beds are considered to be a non-renewable resource. Maerl beds are also fragile habitats that support many rare, unusual and scientifically interesting species and as such are of particular international conservation interest (Bosence, 1979; Blunden et al., 1981; Bellan-Santini et al., 1994; Hall-Spencer, 1998; Sánchez-Mata et al., 1999). In comparison with other continental shelf sedimentary habitats, maerl bed biodiversity is impressive (Picard, 1965; Grall and Glémarec, 1997a, b; Sánchez-Mata et al., 1998).

Picard (1965) was among the first to point out the high biodiversity of Mediterranean maerl beds, which he described as facies with free-living calcareous algae. Seminal work in this area was carried out by Jacquotte (1962) who studied the macroflora and fauna of several maerl beds in the Atlantic and Mediterranean. Falconetti (1970) later studied the fauna of maerl beds in Algeria while Irish maerl fauna 
was investigated by Keegan (1974) and Bosence (1979). Other studies focused on particular taxa associated with maerl beds: for example, Blunden et al. (1977) and Ballesteros (1989) studied the flora of maerl bottoms in Brittany and Spain, respectively, maerl infauna was studied by Cabioch (1968) in Brittany, Mora (1980) in northwest Spain, and Rowe et al. (1990) in southwest England. Hall-Spencer (1998) made a baseline survey of maerl-associated molluscs in Scotland and Ramos-Esplá (1992) investigated the ascidians on this type of bottom in Spain. All these studies have highlighted the rich biodiversity associated with these grounds. The BIOMAERL project confirmed these observations, providing an extensive inventory of maerl-associated biota from sites throughout Europe. Table 1 lists the number of species in each taxon recorded during the BIOMAERL project; macroalgae, annelids, crustaceans and molluscs were particularly diverse on several maerl grounds with $>100$ species per site.

Apart from high species richness, maerl beds also show a high functional diversity (Grall and Glémarec, 1997b; DeGrave and Whitaker, 1999). Grall and Glémarec (1997b) categorized the biota of a Breton maerl into eight trophic groups. This high functional diversity is again attributable to the structural complexity of the habitat coupled with the interactions between organisms (e.g. competition, grazing and predation). The architecture of maerl habitats is such that they provide good shelter for invertebrate predators from larger predators. These invertebrate predators may maintain the number of prey species below levels of competitive exclusion, thus preventing resource monopolization (Grall and Glémarec, 1997b). Such biotic interactions are thought to be important in regulating the stability of the substratum, the availability of food and refugia, and reproduction, and therefore in influencing diversity and productivity of marine ecosystems (Brenchley, 1981; Sousa, 1984).

Maerl beds can also be of importance to sustainable fisheries, providing nursery grounds for commercial species of fish and shellfish (Thouzeau, 1991; Sánchez-Mata et al., 1998; Hall-Spencer et al., 2003; Steller et al., 2003). Many northeast Atlantic maerl beds are productive fishing grounds for scallops and infaunal bivalves (Hall-Spencer et al., 2003) and Mediterranean maerl beds are often targeted for demersal fish and cephalopods (Massutí et al., 1996; Borg et al., 1998).

In addition, maerl beds can also be considered as 'carbonate factories' as they have a much higher carbonate production than other coastal communities around Europe (Freiwald and Henrich, 1994; Canals and Ballesteros, 1997). The production of carbonates by benthic communities is of global significance since it may affect the Earth's climate. A calcium carbonate deposition rate of $876 \mathrm{~g} \mathrm{~m}^{-2} \mathrm{y}^{-1}$ was reported for Lithothamnion corallioides in the Bay of Brest, France by Potin et al. (1990). For the western Mediterranean, Canals and Ballesteros (1997) quote an algal carbonate production rate of $210 \mathrm{~g} \mathrm{~m}^{-2} \mathrm{y}^{-1}$.

Table 1. The number of species in each taxon recorded during the BIOMAERL project in three northeast Atlantic and two Mediterranean sites

\begin{tabular}{|c|c|c|c|c|c|}
\hline \multirow{2}{*}{ Taxon } & \multicolumn{3}{|c|}{ Atlantic } & \multicolumn{2}{|c|}{ Mediterranean } \\
\hline & Clyde Sea (Scotland) & Brittany & Galicia & Alicante & Malta \\
\hline Macroalgae & 66 & 58 & $16^{*}$ & 168 & 104 \\
\hline Porifera & 10 & 8 & 3 & $5^{*}$ & 1 \\
\hline Cnidaria & 35 & 14 & 9 & $11^{*}$ & 2 \\
\hline Annelida & 120 & 165 & 174 & $78^{*}$ & $57^{*}$ \\
\hline Crustacea & 104 & 137 & 107 & 103 & 83 \\
\hline Mollusca & 138 & 115 & 96 & $99^{*}$ & 100 \\
\hline Echinodermata & 26 & 20 & 19 & $24^{*}$ & 13 \\
\hline Bryozoa & 22 & $0_{*}$ & $0^{*}$ & $9^{*}$ & $8^{*}$ \\
\hline Ascidiacea & 11 & 4 & 4 & 14 & 4 \\
\hline Pisces & 32 & 12 & 8 & 15 & 17 \\
\hline Others & 58 & 24 & 11 & 16 & 11 \\
\hline Totals & 622 & 557 & 447 & 542 & 400 \\
\hline
\end{tabular}

${ }^{*}$ Groups that are still being studied and the actual species richness will be much higher. 


\section{HUMAN IMPACTS ON MAERL BEDS}

In spite of their economic and ecological importance, maerl beds are under threat from human activities, including: land reclamation (e.g. creation of artificial beaches); coastal structures that change the nature of the local marine environment (e.g. breakwaters, quays, sea-walls and yacht marinas); effluent discharges (e.g. domestic and/or industrial wastes discharged through short pipelines); offshore dumping (e.g. domestic and/or sewage sludge and industrial waste discharged at sea through long pipelines; dumping of harbour dredged sediments); extraction (direct exploitation of maerl for use as a soil conditioner; extraction of sand for artificial beaches); bottom fisheries (dredging and bottom trawling); aquaculture (mussel rafts and fish cages); recreation (mooring of boats); and alien species (e.g. the macroalga Caulerpa taxifolia in the Mediterranean and the slipper limpet Crepidula fornicata in Brittany).

These threats can produce direct and indirect effects that can be divided into three interrelated groups:

Physical impacts: e.g. reduction of light penetration due to sediment resuspension, such as when sediment is dumped or sewage is discharged; alteration of inshore currents such as caused by coastal structures; burial of live maerl by land reclamation or towed demersal fishing gears; granulometric changes as by an increase in the silt-clay fraction.

Chemical impacts: e.g. increase in organic matter and in nutrients (the latter leading to eutrophication) as caused by sewage outfalls, below and in the vicinity of aquaculture units, and when sediment is resuspended by towed demersal fishing gears.

Biological impacts: e.g. decrease of habitat complexity, as when the physical structure of maerl-associated algae is altered, resulting in a decrease in species richness and abundance; changes in species composition such as the substitution of $\mathrm{K}$-selected species by opportunistic ones (r-selected species), the substitution of hard-bottom species with soft-bottom ones, or the substitution of indigenous biota by alien species.

The BIOMAERL programme considered these three main areas in relation to threats to European maerl resources. One of the most obvious threats is commercial extraction, as this has led to the wholesale removal of maerl habitats (e.g. from five sites around the coasts of Brittany) whilst areas adjacent to extraction sites show significant reductions in diversity and abundance (BIOMAERL, 1999). Even if the proportion of living maerl in commercially collected material is low, extraction has major effects on the wide range of species present in both live and dead maerl deposits (Hall-Spencer, 1998). Brittany is the main area for maerl extraction with about $500000 \mathrm{t}$ extracted annually; smaller amounts are extracted in SW England and southwest Ireland. The maerl is marketed mainly for use as an agricultural fertilizer. Other uses include: as an animal food additive, for biological de-nitrification and in neutralization of acidic water in the production of drinking water, aquarium gravel as well as in the pharmaceutical, cosmetics, nuclear and medical industries (Blunden et al., 1977; Briand, 1989; De Grave et al., 2000). These uses are all related to the chemical composition of maerl, which is primarily composed of calcium and magnesium carbonates.

The effects of eutrophication on maerl grounds have been documented in Galicia, where there is high organic input as a result of mussel aquaculture (Sánchez-Mata, pers. comm.), as well as in the Bay of Brest, where eutrophication is due to run-off from surrounding agricultural land (BIOMAERL, 1998). One effect is an increase in fine particles that clog maerl interstices and so reduce the permeability of the deposit. This reduces the number of microhabitats, decreasing the species richness (Grall and Glémarec, 1997b; Grall and Hall-Spencer, 2003). Species that are typical of maerl become replaced by others that are characteristic of fine sediments with a high organic content (Sánchez Mata et al., 1999). In both Galicia and Brest, a reduction in the abundance and number of suspension feeders, micrograzers and carnivores was also observed. This indicates that eutrophication causes a decrease in the functional diversity of maerl systems (BIOMAERL, 1999).

Recent studies on the fishing intensity and area swept by fishing gear (e.g. Rijnsdorp et al., 1998), indicate that most sedimentary benthic systems on the continental shelf of Europe have been modified by fishing activities in the last 100 years. This represents one of the major threats to European maerl habitats as towed 
demersal fishing gears can have a profound impact on maerl beds through reductions in complexity, biodiversity and long-term viability of the habitat (Hall-Spencer and Moore, 2000a,b). These ancient biogenic habitats are vulnerable because regeneration depends upon a surface layer of live thalli, which can be buried and killed by the gear (Hall-Spencer, 1998). Scallop dredges, which are widely used on northeast Atlantic maerl beds, have teeth that penetrate $c a 10 \mathrm{~cm}$ into the sediment. These dredges can erase natural bottom features and lead to long-term ( $>5$ year) reductions in live maerl cover. Also, scallop dredging compacts the open-lattice superficial layer usually present in maerl beds and brings fine particles to the surface. When compared to samples collected in Scotland between 1885 and 1891, the present abundance of maerl in impacted areas was much lower and thalli were smaller in size (Hall-Spencer and Moore, 2000a).

The major anthropogenic impact on W. Mediterranean maerl beds is due to otter trawling which is the most important fishing activity in this area (Oliver, 1983). Otter trawling can cause physical and biological degradation of benthic habitats (Sánchez-Lizaso et al., 1990) and is carried out illegally in some inshore waters, including maerl beds off Malta (Borg et al., 1998), Alicante (Bordehore et al., 2000) and Majorca (Massutí et al., 1996). The impacts of otter trawling on the maerl beds off southwest Spain are similar to those of scallop dredging on Atlantic coasts, including breaking and eroding of the maerl. Trawled beds off Alicante had more fine sediment and opportunistic species than on protected maerl grounds, which had more long-lived, K-selected species (species adapted for life in stable predictable environments rather than for life in environments subject to periodic disturbance). Corallinaceae were more diverse and abundant at an untrawled site while the dominant maerl-former, Lithothamnion corallioides, was replaced by faster growing Peyssonnelia orientalis at a trawled site (Bordehore et al., 1999).

However, the degree to which maerl beds are fished is unknown in most areas and it is difficult to distinguish between naturally induced disturbance and anthropogenic disturbance. In Malta, otter trawling did not appear to have a significant impact on the maerl beds studied, probably because such fishing, being illegal, only occurred sporadically. Fishing with set trammel nets leads to selective removal and mortality of large rhodoliths (maximum size recorded: $85.9 \mathrm{~mm}$ longest diameter) as they become entangled within the nets (Borg et al., 1998). The removal of the largest rhodoliths might lead to long-term shifts in maerl community structure on Maltese grounds, given their slow rate of growth.

Thus the BIOMAERL programme has documented a general regression and degradation of European maerl grounds due a range of anthropogenic disturbances. The main impacts differ between northeast Atlantic and Mediterranean maerl beds, due to differences in extraction potential (high vs low), depth distribution $(<30 \mathrm{~m}$ vs $<180 \mathrm{~m}$ ), fishery potential (bivalve molluscs vs fish), as well as physicochemical differences (mesotrophic vs oligotrophic) which can ameliorate the effect of eutrophication. Table 2 provides a generalised comparison of anthropogenic impacts on northeast Atlantic and Mediterranean maerl beds.

Table 2. Threats of northeast Atlantic and Mediterranean maerl beds: (d) direct effect; (i) indirect effect.

\begin{tabular}{|c|c|c|}
\hline Threats & Northeast Atlantic & Mediterranean \\
\hline Land reclamation & (d) +++ & (i) ++ \\
\hline Coastal structures & (d) +++ & (i) ++ \\
\hline Direct effluent discharges & (d) +++ & (i) ++ \\
\hline Off-shore dumping & (i) + & (d) +++ \\
\hline Extraction & (d) +++ & (i) + ; (d) +++ \\
\hline Fishing trawl gears & (d) +++ & (d) +++ \\
\hline Aquaculture & (d) +++ & (d) +++ \\
\hline Recreation & (d) ++ & - \\
\hline Alien species & (d) ++ & (d) ++ \\
\hline
\end{tabular}

Note: $(+++)$ very important; $(++)$ important; $(+)$ can be affected; $(-)$ not affected. 


\section{CONSERVATION AND MANAGEMENT STRATEGIES}

Maerl beds represent a non-renewable resource as extraction and disruption far out-strips their slow rate of accumulation. Scientists, managers and policy makers have been slow to react to an escalating degradation of these habitats such that there is now an urgent need to protect these systems from severe human impacts.

The European Union's Council Directive 92/43/EEC of 21 May 1992 on the conservation of natural habitats and of wild fauna and flora has become known as the 'Habitats Directive'. In brief, this directive establishes a common framework for the conservation of animals, plants and natural habitats of interest to Union Member States, and provides for the creation of a network of Special Areas of Conservation (SACs) called 'Natura 2000 sites'. Two key maerl-forming species, Lithothamnion corallioides and Phymatolithon calcareum, are listed in Annex V (species whose exploitation is subject to management) of the Habitats Directive but several other species form maerl in European waters (Irvine and Chamberlain, 1994; Lanfranco et al., 1999). Some of the unlisted species appear to have highly restricted distributions (Birkett et al., 1998) and should certainly be legally protected.

In Scotland, maerl beds were included by Scottish Natural Heritage in its designation plans for SACs under the Natura 2000 initiative (BIOMAERL, 1999). Marine Conservation Areas have also been declared on the basis of the presence of maerl beds, amongst other habitats of importance, as in the case of the Marine National Park in the Iroise Sea off Brittany.

While maerl is not listed as a habitat type in the 1991 CORINE habitat classification (the EU's habitat classification, originally used by the Habitats Directive) or in its later revisions (its extension in 1993 to cover the whole Palaearctic region, and the PHYSIS computer database; European Commission, 1999), maerl does occur within some of the habitats listed (for example, 'Large shallow inlets and bays' and 'sandbanks slightly covered by sea water all of the time'). However, the European Environment Agency in association with the European Topic Centre on Nature Conservation have produced an extension of the CORINE and Palaearctic systems known as EUNIS (Davies and Moss, 1998) in which maerl habitats are included. Although one stated aim of EUNIS is to support the development of the EU Natura 2000 network and the possible revision of Annex I of the Habitats Directive, it is not yet in use.

As part of the current expansion of the European Union, the European Commission is considering revising the species and habitats of the annexes of the Habitats Directive to include those of concern to applicant member states. It is expected that maerl-forming species and maerl habitats will be included in any revised Directive.

For the Mediterranean, Decree 1626/94 of the European Union on conservation of Mediterranean living resources has a bearing on the conservation of maerl beds since it prohibits demersal trawling in the waters shallower than $50 \mathrm{~m}$. However, the importance of conserving Mediterranean maerl habitats was recognized as early as 1990 when 'les fonds de maerl' were included in the Red Data Book of threatened marine vegetation published by the Mediterranean Action Plan of the United Nations Environment Programme (UNEP/IUCN/GIS Posidonie, 1990). This document had no legislative standing but it served to highlight species and habitats in need of protection, most of which were later incorporated in international treaties protecting the Mediterranean marine environment.

The Convention for the Protection of the Mediterranean Sea against Pollution (1976) led to a protocol concerning Mediterranean Specially Protected Areas in 1982, which was amended and renamed the Protocol for Specially Protected Areas and Biodiversity in the Mediterranean (SPABIM) in 1995. Parties to this protocol are obliged to establish protected areas and to undertake all actions necessary in order to protect these areas and, as appropriate, to restore them as rapidly as possible. They are also required to take measures with regards to the planning and management of these protected areas and to develop scientific and technical research. A number of species are listed as endangered, threatened or whose exploitation is regulated. Although no maerl-forming species are included in the appendices, 'associations 
with rhodoliths' and 'maerl facies' are included as habitat types for the selection of sites to be included in national inventories of natural sites of conservation interest as required by the Protocol.

Maerl habitats are indirectly protected by the Bern Convention (Convention on the Conservation of European Wildlife and Natural Habitats; Council of Europe, 1996) since maerl provides a habitat for certain species listed as 'strictly protected' or 'protected' in the appendices to the convention (for example, the rare Mediterranean kelps Laminaria rodriguezii and L. ochroleuca). Potential for the conservation of maerl habitats also exists under the Convention for the Protection of the Marine Environment of the North-East Atlantic (the 'OSPAR Convention') which entered into force in early 1998 and whose Annex V contains provisions with regard to the protection and conservation of the ecosystems and biological diversity of the convention area.

The sustainable utilization of resources has become a high priority in marine ecosystem management (Birkett et al., 1998). Based on the results of the BIOMAERL programme, several conservation and management strategies were recommended by BIOMAERL (1999), set in the wider context of marine conservation priorities in coastal seas. These are:

- In the context of gravel extraction, maerl grounds should be regarded as essentially non-renewable resources. (For example, in France, maerl extraction is now considered to be 'mining' which implies more constraints for the extractors and more controls on the impact of extraction.)

- Commercial extraction of maerl should not be expanded beyond present limits.

- The exploitation of shellfish associated with maerl grounds by means of heavy towed fishing gears (e.g. scallop dredges) should be prohibited over selected maerl grounds. In order to ensure that this happens, the establishment of artificial barriers on the most sensitive maerl grounds should be considered. The use of set gears, however, may be benign in some cases.

- Exploitation of maerl beds for surface-dwelling molluscs can be achieved without disruption of nontarget organisms. Asset-stripping of the target organisms, however, remains a potential problem.

- A moratorium on the issue of further licences permitting the installation of mariculture cages/rafts over unexploited maerl beds should be put into place.

- The mooring of fixed-cage aquaculture facilities for fin-fish or bivalve molluscs above maerl beds should be discouraged generally, to avoid smothering the bottom with waste food, faeces and/or pseudofaeces. A single anoxic event precipitated by high organic loading of the sediment could result in irreversible loss of living maerl.

- Existing mariculture facilities over maerl grounds should have monitoring of the impacts on the maerl ecosystem built into statutory environmental quality standards.

- Permanent anchorages should not be established over maerl beds, to avoid mechanical attrition of maerl by ground tackle.

- The designation of 'no-take' reserves should prioritise the maerl-bed resources in the vicinity.

- Measures should be taken to limit the impact of practices that might adversely affect the turbidity of the water over maerl beds (for example, coastal construction works, landfill, channel and harbour dredging).

- Measures to counter eutrophication of estuaries having maerl beds at the mouth should be set in train.

- A programme of monitoring of the 'health' of European maerl beds requires to be initiated, and sensitive, efficient and cost-effective indices of health, developed.

- An improved awareness of the biological importance of maerl beds needs to be fostered at all levels. In particular, the fragility of these grounds needs to be understood by fishers.

- Consideration of maerl-related issues needs to be included in discussions of coastal zone management.

- More research is still needed. We remain insufficiently informed about where the best maerl grounds are to be found, how big they are, how long they take to form, how productive they are, how different they are one from another, how they change with time, how they interact with surrounding habitats and exactly how long they take to recover from disturbance. The lack of meiofaunal data for maerl grounds 
remains a major lacuna in knowledge. No ecosystem 'goods and services' approach has ever been applied to furnish a cost-benefit analysis of maerl habitats.

- In order to achieve the conservation aims set out above in a European context, it is desirable that the status of maerl-forming algae be upgraded to give maerl beds a higher category of protection under the EC Habitats Directive, i.e. from being exploited species requiring management under Annex V to a recognized Annex I habitat type or to becoming Annex II species.

In view of the extensive damage to maerl habitats caused by commercial extraction, Environmental Impact Assessments should be mandatory for maerl extraction from any site (DeGrave et al., 2000) bearing in mind that these are non-renewable resources. For effective conservation management, continued study of the distribution, biodiversity and community structure of the European maerl beds is needed. This should include monitoring over time, perhaps using a 'maerl ground biotic index' based on the same philosophy as the United States' Benthic Condition Index (BIOMAERL, 1998; Engle and Summers, 1999). Such an index would incorporate data on edaphic complexity (for example, \% gravels, fines, etc.), basic energy sources (as expressed by the dominance of trophic groups), trophic interactions, and potential perturbation (as expressed by $\%$ biomass of opportunistic species), as an indication of the conservation status of the maerl bed. When calculated over a period of time, such an index would give an indication of the stability or deterioration of maerl grounds.

An obvious way to protect a circumscribed marine habitat type such as maerl, is to designate selected areas as marine protected areas (MPAs), in which certain human activities are restricted. The development of MPAs is gaining widespread attention as an effective tool for conserving biodiversity (Bohnsack and Ault, 1996). The criteria for designating marine protected areas include: the extent of the total area and that of the habitats within it; the variety in terms of species and communities; the 'naturalness' (pristine quality) of the site; the regular occurrence of rare species; the fragility and vulnerability of the habitat, which in turn is a measure of the sensitivity of the habitat to environmental changes; and the 'singularity' (uniqueness) of the habitat.

Maerl beds meet these criteria since they are unique, biogenically produced habitats that occupy discrete and localized areas within coastal waters and which require particular physico-chemical conditions for their formation. They are also easily disrupted by environmental change and are vulnerable to perturbations brought about by human activities. Owing to their slow growth rates, maerl beds are very fragile since depletion of live maerl stock cannot readily be compensated for by the development of new thalli. Moreover, maerl beds show an impressive biodiversity, harbouring many rare and unusual species, not least of which are the maerl-forming algae themselves.

The presence of maerl influenced the selection of Spain's first Marine Nature Reserve (Tabarca Island) established in 1986 (Ramos-Esplá, 1990). The identification of 34 Natura 2000 marine sites in Scotland has been influenced by the existence of important maerl grounds; five of the selected sites contain important maerl beds. Declaring marine protected areas, where certain restrictions apply, is not enough unless these restrictions are enforced. Although very few maerl beds are protected per se in Europe, many are theoretically protected from certain impacts since they occur in zones where other restrictions apply, for example, the prohibition of demersal trawling in the waters shallower than $50 \mathrm{~m}$ that is operative in the EU Mediterranean member states. Nonetheless, such fishing is frequent (Ramos-Esplá et al., 2000). One method that has been effective in preventing such illegal fishing is through the use of artificial reefs (RamosEsplá et al., 2000). These not only form obstacles to towed fishing gear but provide additional habitats and may play a role in protection of the assemblages and biota, including acting as nursery grounds for commercially important species (Seaman and Sprague, 1991).

Whichever management strategies are employed, a programme for monitoring the state of maerl beds is required. There is also a pressing need to improve the awareness of policy makers, the general public and the wider scientific community of the biological importance of maerl beds. This can be achieved by increased publicity and public education (BIOMAERL, 1999). We hope that this special volume of Aquatic Conservation: Marine and Freshwater Ecosystems will provide a timely step in the right direction. 


\section{ACKNOWLEDGEMENTS}

This research has been undertaken in the framework of the BIOMAERL project. We acknowledge the support from the European Commission's Marine Science and Technology Programme (MAST III) under contract MAS3-CT95-0020. The Maltese group are grateful to the Maltese Ministry of Education, the Malta Council for Science and Technology, and the University of Malta for vital financial support.

\section{REFERENCES}

Ballesteros E. 1989. Composición y estructura de los fondos de maërl de Tossa de Mar (Gerona, España) Collectanea Botanica (Barcelona) 17 (2): 161-182.

Basso D. 1996. Adaptive strategies and convergent morphologies in some Mediterranean coralline algae. In Autecology of selected fossil organisms: achievements and problems. Bollettino della Societa Paleontologica Italiana, Cherchi A (ed.); 3, 1-8.

Bellan-Santini D, Lacaze JC, Poizat C. 1994. Les biocénoses marines et littorales de Méditerranée: synthèse, menaces et perspectives. Museum National d'Histoire Naturelle: Paris: 246 pp.

BIOMAERL Team. 1998. Maerl grounds: habitats of high biodiversity in European waters, In Proceedings of the third European Marine Science and Technology Conference, Project Synopses, vol. I, Marine Ecosystems: Lisbon; 169-178.

BIOMAERL Team. 1999. Final Report, BIOMAERL project (Coordinator: P.G.Moore, University Marine Biological Station Millport, Scotland), EC Contract No. MAS3-CT95-0020, 1: 1-541, 2: 542-973 pp. + Appendix.

Birkett DA, Maggs CA, Dring MJ. 1998. An Overview of Dynamic and Sensitivity Characteristics for Conservation Management of Marine SACs, vol. 5. Maerl, [UK Marine SACs Project], Scottish Association for Marine Science, Scotland, $116 \mathrm{pp}$.

Blunden G, Farnham WF, Jephson N, Barwell CJ, Fenn RH, Plunkett BA. 1981. The composition of maerl beds of economic interest in northern Brittany, Cornwall and Ireland. In Proceedings of the Xth International Seaweed Symposium. Walter de Gruyter \& Co.: Berlin; 651-656.

Blunden G, Farham WF, Jephson N, Fenn RH, Plunkett BA. 1977. The composition of maerl from the Glenan Islands of Southern Brittany Botanica Marina 20: 121-125.

Bohsanck JA, Ault JS. 1996. Management strategies to conserve marine biodiversity. Oceanography 9 (1): 73-82.

Bordehore C, Barberá C, Mallol J, Martínez MC, Mena C, Patiño JL, Valle C, Vivas M, Ramos-Esplá AA. 1999. Algal composition and habitat structure in two maërl bottoms: marine reserve of Tabarca and the Island of Benidorm. Proceedings of the First International Workshop on Marine Reserves, Murcia.

Bordehore C, Borg JA, Lanfranco E, Ramos-Esplá AA, Rizzo M, Schembri P. 2000. Trawling as a major threat to Mediterranean maerl beds, presented at the First Mediterranean Symposium on Marine Vegetation, Regional Activity Centre for Specially Protected Areas [UNEP Mediterranean Action Plan], Ajaccio, Corsica, France 2-3 October 2000.

Borg JA, Lanfranco E, Mifsud JR, Rizzo M, Schembri PJ. 1998. Does fishing have an impact on Maltese maerl grounds? ICES Conference on the Ecosystem Effects of Fishing, Hiraklion, Crete.

Bosence DWJ. 1979. Live and dead faunas from coralline algal gravels, Co. Galway. Palaeontology 19: 365-395.

Bosence DWJ. 1983. The occurrence and ecology of recent rhodoliths - a review. In Coated Grains, Peryt TM (Ed.) Springer Verlag: Berlin; 225-242.

Brenchley GA. 1981. Disturbance and community structure: an experimental study of bioturbation in marine softbottom environments. Journal of Marine Research 39: 767-790.

Briand X. 1989. Le Lithothamne: tradition d'hier et agrochimie de demain. Oceanis 15: 693-739.

Cabioch L. 1968. Contribution à la connaissance des peuplements benthiques de la Manche occidentale. Cahiers de Biologie Marine 9 (suppl 5.): 493-720.

Cabioch J. 1969. Les fonds de maerl de la baie de Morlaix et leur peuplement végétal. Cahiers de Biologie Marine 10, 139-161.

Canals M, Ballesteros E. 1997. Production of carbonate particles by phytobenthic communities on the MallorcaMenorca shelf, northwestern Mediterranean Sea. Deep Sea Research 44: 611-629.

Council of Europe. 1996. Convention relative à la conservation de la vie sauvage et du milieu naturel de l'Europe [Rapport T-PVS (96) 102], Council of Europe, Strasbourg, 99 pp.

Davies CE, Moss D. 1998. EUNIS habitat classification: final draft with further revisions to marine habitats. [Work Programme Task 7.5.1], Unpublished report to the European Environment Agency, European Topic Centre on Nature Conservation.

De Grave S, Fazakerley H, Kelly L, Guiry MD, Ryan M, Walshe J. 2000. A study of selected maerl beds in Irish waters and their potential for sustainable extraction [Marine Resource Series 10]. Marine Institute, Dublin, 44 pp. 
De Grave S, Whitaker A. 1999. Benthic community re-adjustment following dredging of a muddy-maerl matrix. Marine Pollution Bulletin 38 (2): 102-108.

Engle VD, Summers JK. 1999. Refinement, validation, and application of a Benthic Condition Index for Northern Gulf of Mexico Estuaries. Estuaries 22 (3A): 624-635.

European Commission. 1999. Interpretation manual of European Union habitats EUR15/2, European Commission DG Environment, Brussels, 119 pp.

Falconetti C. 1970. Etude faunistique d'un faciès: 'La gravelette' ou maërl de Castiglione (Algérie). Tethys 1(4): 10571096.

Freiwald A, Henrich R. 1994. Reefal coralline algal build-ups within the Arctic Cycle: morphology and sedimentary dynamics under extreme environment seasonality. Sedimentology 41: 963-984.

Grall J, Glémarec M. 1997a. Using biotic indices to estimate macrobenthic community perturbations in the Bay of Brest. Estuarine, Coastal and Shelf Science 44 (Suppl. A): 43-53.

Grall J, Glémarec M. 1997b. Biodiversité des fonds de maerl en Bretagne: approche fonctionnelle et impacts anthropogeniques. Vie et Milieu 47(4): 339-349.

Grall J, Hall-Spencer JM. 2003. Problems facing maerl conservation in Brittany. Aquatic Conservation:Marine and Freshwater Ecosystems. 13: S55-S64.

Hall-Spencer JM. 1998. Conservation issues relating to maerl beds as habitats for mollusks. Journal of Conchology, Special Publication 2: 271-286.

Hall-Spencer JM, Grall J, Moore PG, Atkinson RJA. 2003. Bivalve fishing and maerl bed conservation in France and the UK-retrospect and prospect. Aquatic Conservation: Marine and Freshwater Ecosystems 13: S33-S41.

Hall-Spencer JM, Moore PG. 2000a. Scallop dredging has profound, long-term impacts on maerl habitats. ICES Journal of Marine Science 57: 1407-1415.

Hall-Spencer JM, Moore PG. 2000b. Impacts of scallop dredging on maerl grounds. In Effects of Fishing on Non-Target Species and Habitats: Biological, Conservation and Socio-Economic Issues. Kaiser MJ, de Groot SJ. (eds). Blackwell Science: Oxford; 105-117.

Irvine LM, Chamberlain YMC. 1994. Seaweeds of the British Isles, vol. 1, Part 2B. British Museum (Natural History): London, $276 \mathrm{pp}$.

Jacquotte R. 1962. Etude des fonds de maërl de Méditerranée. Recueils des travaux de la Station marine d'Endoume 26 (41): 141-235.

Keegan BF. 1974. The macrofauna of maerl substrates on the west coast of Ireland. Cahiers de Biologie Marine 15: 513530 .

Lanfranco E, Rizzo M, Hall-Spencer J, Borg JA, Schembri PJ. 1999. Maerl-forming coralline algae and associated phytobenthos from the Maltese Islands. The Central Mediterranean Naturalist 3 (1): 1-6.

Littler MM, Littler DS, Hanisack MD. 1991. Deep-water rhodolith distribution, productivity, and growth history at sites of formation and subsequent degradation. Journal of Experimental Marine Biology and Ecology 150: 163-182.

Massutí E, Reñones O, Carbonell A, Oliver P. 1996. Demersal fish communities exploited on the continental shelf and slope off Majorca (Balearic Islands, NW Mediterranean. Vie et Milieu 46 (1): 45-55.

Mora J. 1980. Poblaciones bentónicas de la Ría de Arosa, Tesis Doctoral. Universidad de Santiago, 335 pp.

Norse EA (ed.), 1993. Global Marine Biological Diversity: a Strategy for Building Conservation into Decision Making. Island Press: Washington; 384 pp.

Oliver P. 1983. Les resources halieautiques de la Mediterranee, Premiere Partie: Mediterranee Occidentale. Studies and Reviews of the General Fisheries Council of the Mediterranean 59: 135.

OSPAR. 1998. OSPAR strategy on the protection and conservation of the ecosystems and biological diversity of the maritime area [Reference number: 1998-19], OSPAR Convention for the Protection of the Marine Environment of the North-East Atlantic, Ministerial Meeting of the OSPAR Commission, Sintra: 22-23 July 1998; 3 pp.

Parsons TR. 1992. Biological coastal communities: productivity and impacts, in Coastal syystems studies and sustainable development. UNESCO Technical Papers in Marine Science 64: 27-37.

Picard J. 1965. Recherches qualitatives sur les biocoenoses marines des substrats meubles dragables de la région marseillaise. Recueils des travaux de la Station marine d'Endoume 31 (47): 5-137.

Potin P, Floc'h JY, Augris C, Cabioch J. 1990. Annual growth rate of the calcareous red alga Lithothamnion corallioides (Corallinales, Rhodophyta) in the Bay of Brest, France. Hydrobiologia 204/205: 263-267.

Ramos-Esplá AA. 1992. Ascidias litorales del Mediterráneo ibérico: faunística, ecología y biogeografía. Universidad de Alicante, Alicante, $410 \mathrm{pp}$.

Ramos-Esplá AA, Guillén JE, Bayle JT, Sánchez-Jérez P. 2000. Artificial antitrawling reefs off Alicante, South-Eastern Iberian Peninsula: evolution of reefs block and set design. In Artificial Reefs in European Waters Jensen A, Collins K (eds). Kluwer Academic Publishers: London; 195-217. 
Ramos-Esplá AA. 1990. The marine reserve of Nueva Tabarca (Alicante, Spain). Management aspects. In Parchi marini del Mediterraneo. Aspetti naturalistici e gestionali. Cossu A, Gazale V, Milella I (eds). ICM/Universitá di Sassari/CO.RI.SA: San Teodoro; 107-117.

Rijnsdorp AD, Buijs AM, Storbeck F, Visser EG. 1998. Micro-scale distribution of beam trawl effort in the southern North Sea between 1993 and 1996 in relation to the trawling frequency of the seabed and the impact on benthic organisms. ICES Journal of Marine Science 55: 403-419.

Rowe GA, Sheader M, Jensen AC. 1990. The infauna of Handfast Point maerl bed, [Report No. SUDO/TEC/90/16C] Nature Conservancy Council, Peterborough, $57 \mathrm{pp}$.

Sánchez-Mata A, Abella FE, Mora J. 1998. Biodiversidad específica de los fondos de maerl Lithothamnion corallioides (P. \& H. Crouan) P. \& H. Crouan y Phymatholithon calcareum (Pallas) Adey \& McKibbin de la Ría de Vigo. In Proceedings of the 10th Simposio Ibérico de Estudios del Bentos Marino, Universidade do Algarve, Praia de Carvoeiro; $168-169$.

Sánchez-Mata A, Lastra M, de la Huz Ch, Pita ME, Mora J. 1999. The maerl grounds as islands of high biodiversity in temperate latitudes: the Galician case. In Proceedings of the 34th European Marine Biology Symposium, Universidade dos Acores. Ponta Delgada; 77-78.

Sánchez-Lizaso JL, Guillén JE, Ramos-Esplá AA. 1990. The regression of Posidonia oceanica meadows in El Campello. Rapports C.I.E.S.M. 32(1): 7.

Seaman W, Sprague LM. 1991. Artificial habitat practices in aquatic systems. In Artificial Habitats for Marine and Freshwater Fisheries, Seaman W, Sprague LM (eds). Academic Press: London; 1-29.

Smith VH, Tilman GD, Nekola JC. 1999. Euthrophication: impacts of excess nutrient inputs on freshwater, marine, and terrestrial ecosystems. Environmental Pollution 100: 179-196.

Sousa WP. 1984. The role of disturbance in natural communities. Annual Review of Ecology and Systematics 15: 353391.

Steller DL, Foster MS. 1995. Environmental factors influencing distribution and morphology of rhodoliths in Bahía Concepción, B.C.S., México. Journal of Experimental Marine Biology and Ecology 194: 201-212.

Steller DL, Riosmena-Rodríguez R, Foster MS, Roberts CA. 2003. Rhodolith bed diversity in the Gulf of California: the importance of rhodolith structure and consequences of anthropogenic disturbances. Aquatic Conservation: Marine and Freshwater Ecosystems 13: S5-S20.

Thouzeau G. 1991. Experimental collection of postlarvae of Pecten maximus (L.) and other benthic macrofaunal species in the Bay of Saint-Brieuc, France. II. Reproduction patterns and postlarval growth of five mollusc species. Journal of Experimental Marine Biology and Ecology 148: 181-200.

UNEP/IUCN/GIS Posidonie. 1990. Livre rouge 'Gérard Vuignier' des végétaux, peuplements et paysages marins menaces de Méditerranée. MAP Technical Report Series 43; United Nations Environment Programme, Athens, $250 \mathrm{pp}$. 